\title{
LITRATURE REVIEW TRAUMA VASCULAR
}

\author{
Muhammad Hardi Tenggara \\ Universitas Mataram, Indonesia \\ Email: mharditenggara@gmail.com
}

\begin{abstract}
Abstrak
Trauma vaskular merupakan trauma pada pembuluh darah yang disebabkan karena cedera tumpul seperti benturan yang keras atau cedera tembus seperti luka benda tajam, tembakan peluru tembus. Perdarahan yang masif adalah penyebab utama trauma vaskuler hingga mengakibatkan kematian. Oleh karena itu dipelukannya penanganan yang cepat untuk menghindari komplikasi lain terjadi atau bahkan kematian karena pendarahan yang tidak terkontrol. Penelitian ini bertujuan untuk memahami dengan secara mendalam tentang trauma vascular. Ada pun metode yang digunakan adalah tinjauan literatur dan meta analisis. Hasilnya yaitu ahli bedah vaskular mengemukakan kunci utama pada pasien cedera trauma, dengan mengoontrol perdarahan dan rekonstruksi vaskular, menggunakan aspek teknik bedah terbuka dan endovascular. Protokol diagnostic diperlukan untuk mengidentifikasi cedera dan mempertimbangkan taktik terbaik untuk perawatan bedah cedera vascular. Teknik pencitraan diagnostik yang akurat, non-invasif, adalah kunci dari strategi ini. Tujuan dari tinjauan ini adalah untuk menentukan pencitraan dari diagnostic yang optimal pada pasien dengan dugaan cedera vaskular di daerah anatomi dan metode pengobatan dengan pengumpulan data retrospektif atau prospektif yang lebih direkomendasikan dengan CT angiografi dibandingkan dengan metode lain. CT angiografi dapat dinyatakan sebagai standar emas untuk mendiagnosis cedera vaskular pada pasien.
\end{abstract}

Kata Kunci: Trauma vascular; Protokol diagnostic; CT angiografi

\begin{abstract}
Vascular trauma is trauma to the blood vessels caused by blunt injuries such as a hard impact or penetrating injuries such as sharp objects, penetrating bullets. Massive bleeding is the main cause of vascular trauma and can lead to death. Therefore, prompt treatment is needed to avoid other complications or even death due to uncontrolled bleeding. This study aims to understand in depth about vascular trauma. The methods used are literature review and metaanalysis. The result is that vascular surgeons put forward the key to trauma injury patients, by controlling bleeding and vascular reconstruction, using aspects of open and endovascular surgical techniques. Diagnostic protocols are needed to identify injuries and consider the best tactics for surgical treatment of vascular injuries. Accurate, non-invasive diagnostic imaging techniques are key to this strategy. The aim of this review is to determine the optimal diagnostic imaging in patients with suspected vascular injury in the anatomic area and the
\end{abstract}


method of treatment with retrospective or prospective data collection which is preferable to CT angiography compared to other methods. CT angiography can be stated as the gold standard for diagnosing vascular injury in patients.

Keywoard: Trauma vascular; Protokol diagnostic; CT angiografi

Diterima: 18-11-2021

Direvisi: 12-12-2021

Diterbitkan: 20-12-2021

\section{Pendahuluan}

Cedera vaskular traumatik merupakan salah satu penyakit dengan status gawat darurat (segera harus ditangani) dan merupakan tantangan bagi ahli bedah trauma. Cedera vaskular traumatik dapat dibagi menjadi tiga yaitu cedera tumpul, cedera tembus dan cedera iatrogenic. Cedera tumpuk dapat terjadi ketika pembuluh darah hancur atau teregang, yang disebabkan akibat kecelakaan lalu lintas atau terjatuh. Sedangkan cedera tembus dapat terjadi ketika pembuluh darah tertusuk, robek atau terputus, yang disebabkan oleh ledakan dan proyektil (peluru dan pecahan peluru). Lalu yang ketiga ialah cedera iatrogenik dari pengobatan invasif modern (Asadullah et al., 2019).

Cedera vaskular dapat mempengaruhi kerusakan pembuluh arteri dan vena besar yang dapat memicu pendarahan, iskemia, hingga resiko kematian (Xu et al., 2019). Trauma vaskular merupakan keadaan yang darurat dalam bidang surgery. Perdarahan dan iskemia merupakan manifestasi klinis utama pada trauma vaskular. Karna bersifat gawat darurat, jika tidak ditangani tepat waktu dapat menyebabkan kecacatan atau bahkan kematian. Perdarahan masif dan cedera dengan kerusakan pada pembuluh darah ekstremitas adalah penyebab umum kecacatan dan kematian (Morales-Uribe et al., 2016).

Konflik bersenjata selama Perang Dunia Pertama dan kedua mengalami evolusi trauma vaskuler dengan tingkat eksplorasi nonterapeutik hingga 56\%. Dampak kerusakan tubuh pada masa perang tersebut adalah seperti masalah pendarahan dan iskemik, cedera, patah tulang hingga amputasi, serta kerusakan pada arteri subklavia dan aksila di ekstremitas atas. Pada 39\% kasus, kerusakan pada arteri ekstremitas disertai dengan patah tulang dan 80-90\% kasus kematian terjadi karena kerusakan pada pembuluh ekstremitas atas (Wahl et al., 2018). Trauma vaskular ekstremitas menimbulkan beberapa dilema yang sulit dalam diagnosis dan pengobatan. Meningkatnya penggunaan senjata berenergi tinggi dalam peperangan modern dikaitkan dengan cedera pembuluh darah yang parah. Dalam Perang Irak (pada awal abad ke-21), proporsi korban trauma mencapai 50\% hingga 70\% (UGLI et al., no date).

Dengan melihat kemajuan yang signifikan dalam penanganan trauma vaskular, para ahli bedah telah menganjurkan pengembangan bedah secara agresif terhadap kecurigaan klinis cedera arteri. Deteksi dan pengobatan cedera vaskular harus dilakukan dalam konteks resusitasi pasien secara keseluruhan sesuai dengan prinsip-prinsip protokol pendukung kehidupan trauma lanjut (ATLS). Pendekatan ini mengakibatkan tingginya tingkat operasi yang tidak diperlukan, dengan menetapkan prosedur untuk 
diagnostic secara selektif dalam menentukan keperluan intervensi operasi (Fortuna et al., 2016).

Dalam dekade terakhir, kemajuan dalam pengelolaan trauma vaskular berfokus pada diagnosisnya. Pada 1990-an investigasi yang dilakukan untuk menangani cedera vaskular serius adalah dengan metode Ultrasonografi dupleks (DUS), angiografi resonansi magnetik (MRA) dan ekokardiografi transesofageal (TOE). Semua metode tersebut terbukti dan merupakan modalitas diagnostik yang akurat bila diterapkan pada trauma vaskuler. Dengan perkembangan lanjutan pada dekade terakhir yaitu Computed Tomography Angiography (CTA) sebagai penyelidikan skrining utama untuk cedera vascular yang tersedia di sebagian besar layanan darurat dan lebih cepat serta memiliki efek samping yang lebih sedikit, mendukung penggunaan teknik diagnosis yang paling halus seperti CT angiografi.

\section{Definisi (Cedera Vaskular Traumatik)}

Trauma vaskuler merupakan trauma pada pembuluh darah yang bisa disebabkan oleh trauma tembus dan trauma tumpul terhadap ektremitas yang jika tidak diketahui dan tidak dilakukan tindakan sedini mungkin akan mengakibatkan hilangnya atau matinya ekstremitas tersebut (Soto et al., 2019).

Trauma pada pembuluh darah menyebabkan ancaman pada fungsi bagian tubuh yang dialiri darah. Trauma vaskuler memerlukan diagnosis dan tindakan penanganan yang cepat untuk menghindarkan akibat fatal berupa amputasi (Hadiyanto, 2012). Trauma vaskular dapat melibatkan kerusakan pembuluh darah arteri dan vena. Perdarahan yang tidak terdeteksi atau tidak terkontrol dengan cepat akan mengarah kepada kematian pasien, atau bila terjadi iskemia akan berakibat kehilangan tungkai, stroke, nekrosis dan kegagalan organ multiple. Trauma vaskular dapat disebabkan oleh luka tajam, luka tumpul, maupun luka iatrogenik. Trauma vaskuler sering terdapat bersamaan dengan trauma organ lain seperti syaraf, otot dan jaringan lunak lainnya atau bersamaan dengan fraktur atau dislokasi pada ekstremitas.

\section{Mekanisme Cedera}

Secara klasik, mekanisme trauma terbagi dua, yaitu trauma tajam dan tumpul.

\section{a. Cedera Tumpul}

Cedera tumpul biasanya terjadi akibat tabrakan kendaraan bermotor, jatuh atau serangan, dengan cedera yang timbul dari benturan langsung dan efek deformasi tidak langsung. Pada cedera tumpul, gaya benturan bervariasi tergantung pada besarnya energi kinetik, kecepatan, dan arah laju. Trauma tulang utama sering dikaitkan dengan pola cedera vaskular tertentu. Deformasi struktur mediastinum selama deselerasi cepat dapat menyebabkan transeksi atau ruptur aorta torakalis desendens pada fiksasinya oleh ligamentum arteriosum. Cedera karena benturan yang keras, seperti jatuh dari ketinggian dan kecelakaan lalu lintas, sering melibatkan beberapa cedera yang mengancam jiwa pada kepala, dada, panggul dan perut dan memiliki risiko tinggi kehilangan banyak darah (Putri et al., 2016).

b. Cedera Tembus 
Criteria cedera tembus tergantung pada karakteristik laju (massa, bentuk, kecepatan, energi kinetik), titik benturan dan jalur melalui tubuh. Cedera tusukan pisau dapat dianggap kecepatan rendah dan energi rendah, tetapi jika jalurnya mengenai jantung atau pembuluh darah utama maka cedera yang diakibatkannya bisa berakibat fatal. Dengan proyektil rudal seperti peluru berkecepatan tinggi menyebabkan cedera langsung di sepanjang jalur rudal, dan juga menghilangkan energi tidak langsung ke jaringan di sekitarnya dengan menciptakan gelombang kejut longitudinal dan gelombang geser kavitasi transversal. Efek kavitasi ini dapat merusak jaringan yang relatif tidak elastis seperti otak atau organ padat. Fragmentasi rudal pada tulang yang menyerang dapat membuat fragmen rudal sekunder yang menghancurkan. Cedera tembus iatrogenik, terutama yang timbul dari kanulasi arteri, dapat menyebabkan perdarahan, pseudo-aneurisma, fistula arteriovenosa, diseksi atau oklusi trombotik.

\section{Patofisiologi cedera}

Hipovolemia adalah salah satu penyebab umum terjadinya syok pada pasien trauma. Pada pasien dengan trauma 30\%, volume darah akan hilang sehingga akan menyebabkan terjadinya hipotensi yang berujung pada penurunan perfusi ke jaringan. Hal ini juga dapat diperparah dengan adanya koagulopati, hipotermi dan asidosis yang disebut sebagai lethal triad. Koagulopati atau pembekuan darah yang terjadi biasanya diakibatkan karena cedera pada jaringan. Pada trauma vaskular mayor, nyawa pasien terancam karena: perdarahan iskemia regional (oklusi arteri) dan global (syok); dan sindrom respon inflamasi sistemik (SIRS) (Hardisman, 2013).

\section{a. Pendarahan, syok dan koagulopati}

Pada pasien trauma dengan syok, penyebab tersering adalah hipovolemia. Setengah dari semua kematian akibat trauma disebabkan oleh perdarahan dalam 48 jam pertama. Syok hemoragik karena kehilangan lebih dari 30\% volume darah, menyebabkan penurunan tekanan darah dan gangguan perfusi jaringan. Perdarahan masif (perdarahan) secara luas didefinisikan sebagai kehilangan satu volume darah dalam 24 jam, setengah dari satu volume darah dalam waktu 3 jam atau kehilangan darah melebihi $150 \mathrm{ml} /$ menit. Bahaya kehilangan darah yang masif dapat diperparah dengan perkembangan sebuah 'triad mematikan' dari koagulopati, hipotermia dan asidosis. Koagulopati terkait trauma, yang diprakarsai oleh cedera jaringan, sering diperburuk oleh efek pengenceran transfusi dan diperparah oleh hipotermia dan asidosis. Koagulopati terjadi pada sepertiga pasien trauma yang datang dengan perdarahan, dan semua pasien dengan perdarahan masif. Kehadiran koagulopati traumatis secara signifikan meningkatkan terjadinya kegagalan organ ganda dan kematian.

b. Respon inflamasi sistemik

Pada perdarahan masif ada potensi cedera jaringan lokal untuk memicu respon inflamasi sistemik, yang jika tidak terkontrol, dapat menyebabkan sindrom disfungsi multi-organ (MODS) dan kematian. Cedera jaringan lokal dan gangguan integritas seluler memungkinkan mediator pro-inflamasi bersirkulasi. Interaksi komponen darah seluler dan endotel vaskular memulai kaskade amplifikasi pelepasan mediator 
proinflamasi dan aktivasi sel imun, yang jika tidak terkontrol, menjadi SIRS, yang merugikan pejamu. Setelah trauma, terjadi peningkatan konsentrasi serum sitokin dan mediator inflamasi (Lalenoh, 2018).

\section{Faktor-faktor yang mempengaruhi tingkat kecacatan dan amputasi}

Faktor tingkat kecacatan dan amputasi dapat diukur dengan menggunakan skor keparahan cedera/skor keparahan ekstremitas yang hancur, pengobatan yang tertunda untuk cedera vena, dan patah tulang.

a. Cedera senjata api berenergi tinggi

Proyektil berkecepatan tinggi lebih merusak pembuluh darah dan jaringan lain daripada proyektil berkecepatan rendah. Selain itu, respons inflamasi sering terlihat 2 hingga 3 hari setelah cedera, atau bahkan hingga 5 hari setelah cedera jika pembuluh darah yang pecah mengalami trombosis atau terus berdarah.

b. Skor keparahan ekstremitas yang rusak

MESS adalah kriteria pasca trauma objektif yang memprediksi risiko amputasi. MESS mempertimbangkan 4 faktor: tingkat kerusakan tulang dan jaringan lunak; tingkat iskemia tungkai; terkejut; dan usia pasien. MESS memungkinkan dokter untuk menginformasikan pasien dengan hati-hati, untuk mengembangkan rencana perawatan yang komprehensif dari waktu ke waktu, untuk memanfaatkan sumber daya yang tersedia sebaik mungkin, untuk membentuk rencana evakuasi, dan, pada akhirnya, untuk menerapkan perawatan rumah sakit yang sesuai.

\section{c. Cedera Vena}

Sebelumnya, cedera vena hanya diikat, sering memicu flebitis trombotik dan emboli paru. Risiko gangguan refluks vena akut diabaikan; amputasi sering diikuti. perbaikan vena tidak hanya mengurangi edema tungkai tetapi juga meningkatkan patensi arteri jangka panjang. perbaikan vena mengurangi tingkat amputasi. Vena harus diperbaiki sesegera mungkin; ligasi tetap menjadi pilihan saat menghadapi cedera yang mengancam jiwa pada pembuluh darah besar.

d. Fraktur tambahan

Sekitar 33\% dari cedera vaskular dikombinasikan dengan patah tulang, dan sekitar $17 \%$ dengan cedera saraf. Fraktur merupakan faktor risiko independen untuk amputasi. Secara tradisional, fraktur harus dirawat terlebih dahulu, diikuti dengan perbaikan pembuluh darah untuk menghindari kerusakan lebih lanjut pada pembuluh darah yang disebabkan oleh manipulasi tulang yang diperlukan untuk memfiksasi fraktur. Dengan demikian, cedera vaskular harus diperbaiki pertama, diikuti oleh patah tulang dan kerusakan saraf. Ketika sangat penting untuk memperbaiki fraktur pertama, darah harus dikirim melalui selang sementara, diikuti dengan perbaikan pembuluh darah kemudian (Xu et al., 2019).

\section{Metode Penelitian}

Fokus utama dari penelitian ini adalah untuk mengevaluasi diagnostic dan pengobatan khusus pada trauma vaskular, dan bahwa ada lebih dari sepuluh pasien dalam setiap rangkaian kasus. Metode penelitian ini adalah dengan Tinjauan Literatur 
dan Meta Analisis, dimana penelitian berupa laporan kasus atau artikel ulasan atau yang menggambarkan pengobatan cedera vaskular. Artikel yang ditinjau dalam bentuk elektronik atau hard copy. Daftar referensi dicari secara mandiri dan abstrak menjelaskan kondisi yang relevan dan bisa untuk dipertimbangkan, dengan menggunakan panduan literature medis (Dewanto, 2009).

Harus ditekankan bahwa perlunya strategi seorang ahli bedah dalam memberikan perawatan khusus kepada pasien dengan cedera vaskular, terutama pada syok traumatis, tidak bisa dari jenis yang sama. Faktor utama dalam pilihan dan taktik pengobatan harus sesuai dengan kondisi umum pasien; tingkat iskemia; sifat cedera vaskular; formasi anatomi di tungkai dan cedera terkait. Kondisi syok sering diamati pada kehilangan darah akut. Jadi, pada $45-72 \%$ pasien, itu disertai dengan kerusakan pada pembuluh darah besar (Ruswanto, 2010).

\section{Hasil dan Pembahasan}

\section{A. Kasus 1}

Seorang laki-laki 11 tahun dibawa ke unit gawat darurat dengan keluhan luka sayat dengan perdarahan aktif pada lengan bawah kanan. Riwayat medis, riwayat keluarga dan penggunaan obat-obatan atau antikoagulan disangkal. Ibu pasien mengungkapkan bahwa luka terjadi secara tidak sengaja saat pasien sedang bermain dengan gunting. Dia melaporkan bahwa begitu kejadian itu terjadi, kira-kira sebulan yang lalu, pasien itu dibawa ke pusat kesehatan masyarakat di mana luka dikelola dengan penutupan primer. Setelah tujuh hari, dia dibawa kembali denga keluhan massa, sesuai dengan hematoma, dan dehiscence jahitan. Pada saat itu, hematoma dikeringkan dan luka dijahit untuk kedua kalinya. Dua minggu setelah intervensi kedua, pasien dibawa untuk ketiga kalinya ke Puskesmas yang sama untuk drainase hematoma, jahitan luka dan penggunaan perban elastis untuk kompresi. Karena kurangnya perbaikan dan terdapat pendarahan hebat, pasien dirujuk ke pusat perawatan dan dirawat untuk manajemen tujuan dengan diagnosis luka robek di lengan kanan dan kemungkinan darah diskrasia (hemofilia).

Pada pemeriksaan fisik, ia datang dengan kulit pucat dan selaput lendir, terutama pada bagian konjungtiva, dengan mukosa mulut terlihat kering. Tanda-tanda vital stabil. Ekstremitas atas tidak simetris karena luka robek pada aspek volar lengan bawah kanan yang dijahit dengan benang nilon, dengan gambaran perdarahan aktif, non-pulsasi hematoma, nadi perifer terjaga dan tidak adanya tanda-tanda inflamasi. Pasien ditempatkan di ruang rawat inap untuk penilaian hidrasi, pemantauan tanda vital dan pengujian laboratorium.

Hasil yang dilaporkan:

\begin{tabular}{lc}
\hline \multicolumn{1}{c}{ Keterangan } & Nilai \\
\hline Eritrosit & $3,65 \times 106 / \mathrm{mm} 3$ \\
\hline Hemoglobin & $9,6 \mathrm{~g} / \mathrm{dL}$ \\
\hline Hematokrit & $28 \%$ \\
\hline
\end{tabular}




\begin{tabular}{lc}
\hline Volume sel rata-rata & $77 \mu \mathrm{m} 3$ \\
\hline hemoglobin sel rata-rata & $26,5 \mathrm{pg}$ \\
\hline Trombosit & $362 \times 103 / \mathrm{mm} 3$ \\
\hline leukosit & $10.9 \times 103 / \mathrm{mm} 3$ \\
\hline Granulosit & $7.6 \times 103 / \mathrm{mm} 3$ \\
\hline Limfosit & $2,6 \times 103 / \mathrm{mm} 3$ \\
\hline Glukosa & $120 \mathrm{mg} / \mathrm{dL}$ \\
\hline laktat dehidrogenase & $780 \mathrm{~L}$ \\
\hline
\end{tabular}

\section{B. Pembahasan}

Pasien dikonsultasikan dengan Departemen Bedah Vaskular dan, berdasarkan tidak adanya tanda-tanda cedera vaskular yang berat selama pemeriksaan fisik, pemasangan elastis perban dengan kompresi sedang, imobilisasi ekstremitas, dan arteri dan vena Doppler lengan kanan bawah direkomendasikan. Dua hari kemudian, Doppler tidak dapat dilakukan karena teknisi melaporkan pendarahan hebat saat melepas elastis perban. Oleh karena itu, pasien diberikan asam traneksamat $660 \mathrm{mg}$ IV setiap 24 jam. Pada hari keempat masuk, dia dinilai ulang oleh ahli bedah vaskular dan diagnosis kemungkinan cedera vaskular ditambahkan. Mengingat bukti ketidakstabilan hemodinamik, diputuskan untuk mentransfusikan sel darah merah dan melakukan evaluasi pra-anestesi jika terjadi intervensi bedah. Setelah itu, pasien dipindahkan ke ruang operasi untuk vaskular eksplorasi. Di bawah anestesi inhalasi, jahitan dilepas, gumpalan darah dievakuasi dan lesi arteri radial 90\%-95\% diamati. Kontrol proksimal dan distal diperoleh, dan patensi lengkung telapak tangan yang utuh ditentukan. Arteri radial diikat karena ketidakstabilan hemodinamik. Rangkaian pasca operasi lancar dan pasien dipulangkan dalam kondisi umum yang stabil. Selanjutunya ditentukan tindak lanjut yang dijadwalkan di Departemen Bedah Vaskular sebagai pasien rawat jalan.

\section{a. Kasus 2}

Klinik ini memiliki 36 pasien dengan syok hemoragik dan traumatis. Dari mereka: 33 pria $(91,6 \%)$, wanita $3(8,3 \%)$. Kami menemukan, di antara mereka yang dirawat di klinik, 36 pasien dengan syok hemoragik dan traumatis. Jadi, pada 5 pasien, kondisinya sangat serius. Penggunaan angiografi dan MSCT sangat penting untuk diagnosis dini kerusakan pembuluh darah traumatis. Tergantung pada sifat dan lokalisasi kerusakan pembuluh darah pada pasien dengan syok, distribusinya adalah sebagai berikut:

\begin{tabular}{ll}
\hline arteri brakialis -17 & $(12,3 \%)$ \\
\hline arteri femoralis -5 & $(3,6 \%)$ \\
\hline arteri karotis -1 & $(0,7 \%)$ \\
\hline arteri oksipital -1 & $(0,7 \%)$ \\
\hline Subklavia -1 & $(0,7 \%)$ \\
\hline Sinar -2 & $(1,4 \%)$ \\
\hline
\end{tabular}




\begin{tabular}{lc}
\hline Ulnaris -7 & $(5 \%)$ \\
\hline tulang kering (arteri poplitea, arteri dan vena tibialis) -1 & $(0,7 \%)$ \\
\hline
\end{tabular}

\section{Hasil yang dilaporkan:}

Berdasarkan analisis indikator berbagai cedera vaskular dalam pengobatan pasien syok, derajat syok hemoragik ditetapkan. Kami telah mengidentifikasi 4 derajat syok hemoragik

\begin{tabular}{|c|c|c|}
\hline Syok hemografik & $\begin{array}{c}\text { Persentase \% } \\
\text { Pasien }\end{array}$ & Indikasi Kondisi \\
\hline Derajat I & Pada $5(3,6 \%)$ & $\begin{array}{l}\text { - BCC defisit hingga } 15 \% \text {. TD di atas } 100 \mathrm{~mm} \mathrm{Hg} \text {. } \\
\text { - Tekanan vena sentral (CVP) dalam batas normal. } \\
\text { - Kulit sedikit pucat dan peningkatan denyut } \\
\text { jantung hingga } 80-90 \text { denyut / menit, hemoglobin } \\
90 \mathrm{~g} / 1 \text { atau lebih. }\end{array}$ \\
\hline Derajat II & Pada $27(19,5 \%)$ & $\begin{array}{l}\text { - Defisit BCC hingga } 30 \% \text {. Dengan tingkat } \\
\text { keparahan sedang, kelemahan, pusing, } \\
\text { penggelapan mata, mual, lesu, pucat kulit diamati. } \\
\text { - Hipotensi arteri hingga } 80-90 \mathrm{~mm} \mathrm{Hg.} \mathrm{Art.,} \\
\text { penurunan CVP (kolom air di bawah } 60 \mathrm{~mm} \text { ), } \\
\text { takikardia hingga } 110-120 \text { denyut / menit, } \\
\text { penurunan output urin, hemoglobinado } 80 \mathrm{~g} \mathrm{/} \\
\text { dan kurang }\end{array}$ \\
\hline Derajat III & Pada $4(2,8)$ & $\begin{array}{l}\text { - Defisit BCC adalah } 30-40 \% \text {. } \\
\text { - Apalagi kondisinya parah atau sangat parah, lesu, } \\
\text { bingung, kulit pucat, sianosis. } \\
\text { - NERAKA di bawah } 60-70 \mathrm{~mm} \mathrm{Hg.} \\
\text { - Takikardia hingga } 130-140 \text { denyut / menit, } \\
\text { pengisian nadi lemah. Oliguri }\end{array}$ \\
\hline Derajat IV & Pada $1(0,7)$ & $\begin{array}{l}\text { - Defisit BCC lebih dari } 40 \% \text {. } \\
\text { - Tingkat penindasan yang ekstrim dari semua } \\
\text { fungsi vital: tidak ada kesadaran; AD dan CVP; } \\
\text { dan denyut nadi di arteri perifer tidak ditentukan. } \\
\text { - Pernapasan dangkal dan sering. Hiporefleksia. } \\
\text { Anuria. Secara kasar, jumlah kehilangan darah } \\
\text { dapat diperkirakan dengan menghitung indeks } \\
\text { syok. }\end{array}$ \\
\hline
\end{tabular}




\section{Catatan:}

Tes darah laboratorium dilakukan pada 36 pasien dengan latar belakang syok: hemoglobin dari 62 menjadi 109 g / 1 - 22; hematokrit - 6 dari 20 hingga 39\%; 1 PTI 84\%; fibrinogen-4 dari 4210 menjadi $6660 \mathrm{~g} / 1$. dan satu pasien adalah -1776 g / 1 .

Penelitian ini telah melakukan 36 operasi berbeda untuk pasien dengan syok setelah cedera vaskular: ligatur pembuluh darah-19; jahitan lateral-5. Dari mereka: pada saat yang sama dikenakan pembuluh vena jahitan samping. jahitan melingkar-4; pirau otomatis-3; prosthetics 4: amputasi primer - 1 dan 7 pasien dengan jahitan epineural. Bersamaan dengan itu, syok berat, kerusakan jaringan masif dan iskemia ireversibel merupakan indikasi amputasi ekstremitas pada 1 (2,7\%) pasien dengan kerusakan vaskular. Pendarahan arosif diamati, hanya pada satu pasien. Pada $24(94,4 \%)$ pasien, penyembuhan luka primer, pada $2(5,5 \%)$ pasien, luka sembuh dengan niat sekunder.

\section{b. Pembahasan}

Jadi, pada syok derajat I-II, pemulihan aliran darah dilakukan dengan tindakan anti-syok. Dalam kasus syok traumatis dan hemoragik derajat III, operasi rekonstruktif dan restoratif dilakukan setelah stabilisasi parameter hemodinamik. Kami menemukan dari semua yang dirawat di klinik, 36 (26\%) pasien dengan syok hemoragik dan traumatis. Selain itu, pada $5(3,6 \%)$ pasien, kondisinya sangat serius. Pada saat yang sama, kami menentukan tingkat kehilangan darah: 1000-1500 ml - 6; 1500-2000 ml pada $25 ; 2500-3000 \mathrm{ml}$ - pada 5 pasien. Bersamaan dengan ini, kami telah menetapkan tingkat kejutan untuk: -5 pertama (3,6\%); yang kedua - 27 (19,5\%); ketiga - 4 (2,8\%) pasien. Pada saat yang sama, tekanan darah pasien berkisar antara 60/30 hingga 100/60 mm. rt. Seni. dan denyut nadi dari 60 hingga 130 denyut dalam satu menit.

Selama operasi dengan anestesi lokal, selubung pengantar $6 \mathrm{~F}$ dipasang di arteri femoralis di kedua sisi. Selanjutnya, dilakukan oklusi balon total endovaskular sementara pada pembuluh darah arteri. Pada saat yang sama, kateter balon (berukuran 6x60 mm) digunakan untuk memperluas oklusi lengkap dan patensi vaskular. Oklusi terjadi pada tekanan di dalam balon hingga 9 atm dengan RBP 10 atm. Kontras Unigexol- 350 - $100 \mathrm{ml}$ (1 botol $100 \mathrm{ml}$ ). Pada saat yang sama, 3 ribu heparin MED diperkenalkan.

Penentuan defisit volume darah sirkulasi dilakukan sesuai dengan nilai indeks syok dengan metode Algover (perbandingan denyut nadi dengan tingkat tekanan darah sistolik), dan indeks syok adalah volume kehilangan darah (BCC).

Untuk mencegah komplikasi seperti itu, kami menyarankan melakukan perfusi organ iskemik. Untuk ini, komposisi larutan perfusi dibuat: antibiotik spektrum luas (cefuroxome, brolumycin, cyptrioxan) - 1,0; FFP -200ml; rheomacradex $400 \mathrm{ml}$; larutan fisiologis - $500 \mathrm{ml}$; larutan papaverin - $5 \mathrm{ml}$; larutan novocaine-200 ml; 4\% larutan natrium bikarbonat - $150 \mathrm{ml}$; heparin-20000ED; fibrinolisin - $20.000 \mathrm{ED}$; larutan difenhidramin-4 ml. dan hemosorpsi untuk memerangi iskemia ekstremitas akut.

Ligasi arteri vertebralis, ketika terluka di segmen pertama, dilakukan dari pendekatan supraklavikula atau vertikal yang khas. Ketika arteri terbuka di sebelah kiri, 
saluran limfatik toraks dapat diikat. Ligat, semua anak sungai limfatik yang rusak. Arteri diisolasi sepanjang panjangnya, dari mulutnya hingga masuk ke pembukaan proses transversal vertebra C6, dan diikat. Operasi untuk cedera arteri vertebralis, di segmen kedua, jika tidak mungkin ligasi segmen proksimal dari arteri yang ditranseksi, kanal proses transversal dapat ditutup dengan lilin, ditampon dengan otot. Dalam operasi melukai arteri vertebralis, di segmen ketiga, pendarahan dari ujung arteri vertebralis dapat dihentikan dengan tampon otot dengan jahitan yang dalam, lebih dekat ke proses mastoid tulang temporal. Di daun ini, arteri vertebralis terletak paling dangkal dalam kaitannya dengan kulit. Dalam hal ini, pendarahan dihentikan dengan penjahitan pembuluh darah. Jahitan vaskular adalah salah satu tahap yang paling penting dari bedah rekonstruktif vascular.

Ligasi vaskular-19; jahitan samping-5. Dari jumlah tersebut: jahitan lateral pembuluh vena secara bersamaan dikenakan. jahitan melingkar-4; pirau otomatis-3; prosthetics 4 amputasi primer-1 pasien. Pada saat yang sama, 7 pasien menjalani jahitan epineural. Untuk mengatasi masalah taktis dalam keadaan syok pasien, kami dipandu oleh penilaian tingkat keparahan kondisi; sifat cedera dan perkembangan iskemia. Operasi rekonstruktif awal untuk iskemia dan syok yang berkembang pesat, bersama dengan tindakan anti-shock, dilakukan oleh kami pada 36 pasien. Syok berat, kerusakan jaringan masif dan iskemia ireversibel merupakan indikasi amputasi tungkai pada 1 $(2,7 \%)$ pasien. Pendarahan arosif diamati hanya pada satu pasien. Pada $24(94,4 \%)$ pasien, penyembuhan luka adalah primer, pada $2(5,5 \%)$ pasien, luka sembuh dengan niat sekunder.

\section{Kesimpulan}

Trauma vaskular dapat melibatkan kerusakan seperti pembuluh darah arteri dan vena sehingga dapat mengancaman pada fungsi bagian tubuh yang dialiri darah. Oleh karena itu memerlukan diagnosis dan tindakan penanganan yang cepat untuk menghindarkan akibat fatal berupa perdarahan yang tidak terdeteksi atau tidak terkontrol dengan cepat yang akan mengarah kepada cacat, amputasi, bahkan kematian pasien, atau bila terjadi iskemia akan berakibat kehilangan tungkai, stroke, nekrosis dan kegagalan organ multiple. Pentingnya protokol diagnostik yang berfokus pada identifikasi tanda-tanda keras dan lunak dari cedera vaskular, terutama di area dan pusat perawatan primer, untuk menjamin intervensi yang cepat dan menghindari tingkat komplikasi.

Penggunaan angiografi dan MSCT memiliki pengobatan yang efektif untuk diagnosis dini cedera vaskular traumatis. Computed Tomography Angiography (CTA) dapat menggantikan semua modalitas pencitraan lainnya ketika digunakan sebagai investigasi lini pertama untuk dugaan cedera vaskular traumatis. CTA memiliki keakuratan yang tinggi, cepat dilakukan, non-invasif, tersedia dan dapat mencitrakan daerah anatomi lainnya secara bersamaan. CTA bersifat diagnostik dan membantu dalam perencanaan manajemen endovaskular. Cedera dan kerusakan jaringan lain akan terdeteksi secara cepat dengan modalitas CTA. Efisiensi tinggi dari penggunaan tepat 
waktu dari operasi rekonstruktif dan restoratif - pencangkokan pembuluh darah bypass autovenous setelah stabilisasi parameter hemodinamik tergantung pada tingkat syok traumatis dan hemoragik melalui oklusi lengkap pembuluh darah. 


\section{BIBLIOGRAFI}

Asadullah, A., Harmawan, E. W., Prastikarunia, R., Putra, G. H., Kustono, H., Utama, S., Artha, K. S. A., Apriawan, T. and Bajamal, A. H. (2019) 'MANAJEMEN TRAUMA TEMBUS OTAK: LAPORAN KASUS', Molucca Medica, pp. 34-44. Google Scholar

Dewanto, G. (2009) 'Panduan praktis Diagnosis dan tata laksana penyakit saraf', in. EGC. Google Scholar

Fortuna, G., DuBose, J. J., Mendelsberg, R., Inaba, K., Haider, A., Joseph, B., Skarupa, D., Selleck, M. J., O'Callaghan, T. A. and Charlton-Ouw, K. (2016) 'Contemporary outcomes of lower extremity vascular repairs extending below the knee: A multicenter retrospective study', Journal of Trauma and Acute Care Surgery. LWW, 81(1), pp. 63-70. Google Scholar

Hadiyanto, L. (2012) 'Perbedaan Kejadian Asfiksia Neonatorum pada Kehamilan dengan Preeklamsia Ringan dan Kehamilan Normal di RSUD Dr. Moewardi'. UNS (Sebelas Maret University). Google Scholar

Hardisman, H. (2013) 'Memahami patofisiologi dan aspek klinis syok hipovolemik: Update dan penyegar', Jurnal Kesehatan Andalas, 2(3), pp. 178-182. Google Scholar

Lalenoh, D. C. (2018) Preeklampsia Berat dan Eklampsia: Tatalaksana Anestesia Perioperatif. Deepublish. Google Scholar

Morales-Uribe, C., Ramírez, A., Suarez-Poveda, T., Ortiz, M. and Sanabria, A. (2016) 'Diagnostic performance of CT angiography in neck vessel trauma: systematic review and meta-analysis', Emergency radiology. Springer, 23(5), pp. 421-431. Google Scholar

Putri, C. M. and Sidharta, B. (2016) 'Hubungan antara cedera kepala dan terjadinya vertigo di rumah sakit Muhammadiyah lamongan', Saintika Medika, 12(1), pp. 16. Google Scholar

Ruswanto, B. (2010) 'Analisis spasial sebaran kasus tuberkulosis paru ditinjau dari faktor lingkungan dalam dan luar rumah di Kabupaten Pekalongan'. UNIVERSITAS DIPONEGORO. Google Scholar

Soto, J. E., Vásquez, D. M., Rodríguez, G. and De La Cruz, L. A. (2019) 'Peripheral Vascular Trauma in Pediatrics: A Case Report and Literature Review', Cureus. Cureus Inc., 11(9). Google Scholar

UGLI, Z. N. and TINIBEKOV, M. X. (no date) 'Surgical Treatment of Vascular Injury with Traumatic Shock', JournalNX. Novateur Publication, 6(10), pp. 274-280. Google Scholar

Wahl, U., Kaden, I., Köhler, A. and Hirsch, T. (2018) 'Vascular trauma of the hand-a systematic review', Vasa. Hogrefe AG. Google Scholar

Xu, Y., Xu, W., Wang, A., Meng, H., Wang, Y., Liu, S., Li, R., Lu, S. and Peng, J. 
(2019) 'Diagnosis and treatment of traumatic vascular injury of limbs in military and emergency medicine: a systematic review', Medicine. Wolters Kluwer Health, 98(18). Google Scholar

First publication right:

Jurnal Syntax Fusion: Jurnal Nasional Indonesia

This article is licensed under:

(c) (7) (?) 